\title{
Economic Study of water rationalization in Egypt
}

\author{
Prepared by \\ Dr khloud hossam hassanin \\ Dr Nahla Hassan Ali \\ Assistant professor of economics \\ Doctor of economics
}
Faculty of commerce - department department of Business administration of economics
Al-Azhar university
Higher technological institut

المستخلص

المياه هى أحد الموارد الرئيسية لكل الأنشطة الاقتصادية وأحد الموارد الطبيعية التى و هبها الله تعالى للبشرية

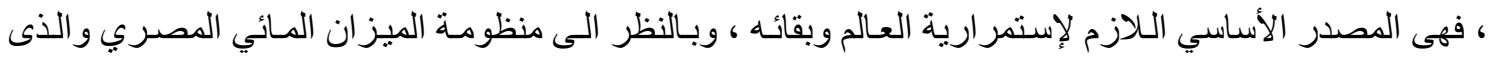

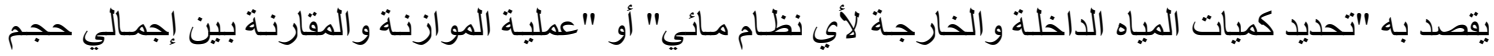

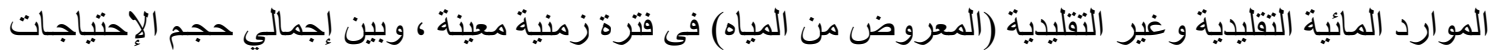



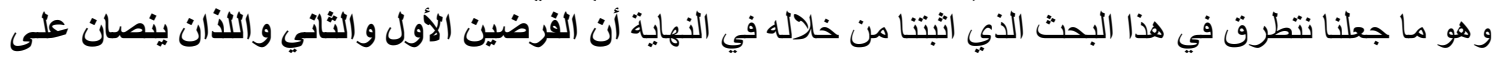



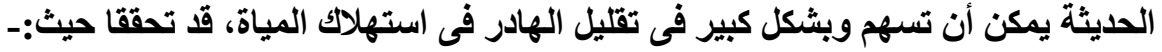

إن متطلبات رأس المال للخمسة أنظمة في الجداول من A1 إلى A8 في نهايـة الدر اسـة، بينت أن التكاليف

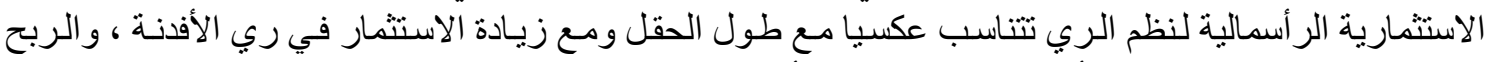

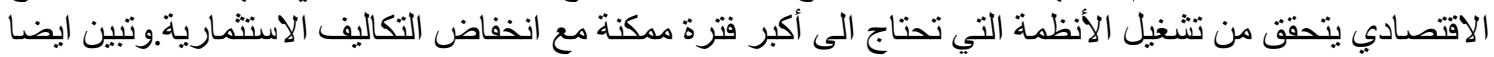

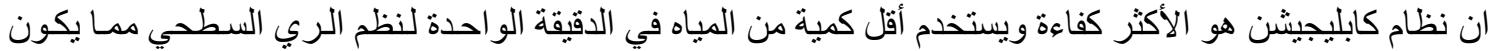


استخدام هذا النظام مقارنة بالانظمة الاخري. 


\section{$\underline{\text { Abstract }}$}

Water is one of the main resources of all economic activities and one of the natural resources that God has given to mankind. It is the essential source for the survival of the world. In the light of the Egyptian water balance system, which means "determining the quantities of water entering or leaving any water system" The total volume of conventional and non-conventional water resources (water supply) over a given period of time, and the total volume of water needs required to meet the various needs (water demand), thus increasing the gap between water supply and demand. The research, in which we proved in the end that the first and second assumptions, which provide the following: The rationalization of consumption of water resources is one of the important alternatives to achieve water security - The application of modern irrigation systems can contribute significantly to reduce the waste water consumption:

The capital requirements for the five systems in tables A1 to A8 at the end of the study illustrated that the capital investment costs of irrigation systems are inversely proportional to the length of the field and with the increasing investment in irrigation of acres. The economic profit is achieved by operating the systems that need the greatest possible time with low costs The system is also the most efficient and uses the smallest amount of water per minute for surface irrigation systems, which is a great reason to rationalize the water of immersion to reduce the costs and narrow the gap between supply and demand of water in the future.

Keyword: Water Resources, Irrigation, pipes, Siphon system, Cablegation system

\section{1-Introduction :}

Egypt relies heavily on the Nile River for its water needs. The Nile River plays a vital role in Egypt's history. Water uses in Egypt are under an increasing pressure, with limited water resources and our future aspirations to increase the cultivated area and expand the agricultural land. The unstoppable population growth and the significant expansion of water use in industry, agriculture and household consumption. The World Bank's 1993 report indicates that the average per capita annual renewable and renewable water resources in the Arab world excluding the underground water reserves will reach 
667 cubic meters in 2025 from 3,430 cubic meters in 1960, 80\%. ${ }^{1}$ This is considered as a lower rate than the annual per capita average of $1000 \mathrm{~m} 3$, and agricultural activity in Egypt consumes the bulk of our water share by up to $88 \%$ of our water resources, which may appear high in number but consistent with the proportions of uses of water resources, In the surrounding countries or the African continent and the world. ${ }^{2}$

Therefore, it is necessary to pay attention to the rationalization of water consumption and use to ensure sustainable agricultural development. It is necessary to rely on three basic pillars. The first pillar is to study the feasibility of rationalizing water which leads to the second pillar that is creating jobs and supporting small producers to increase agricultural crops while reducing the amount of water used to ensure sustainable development for the future generations.

\section{2-The problem of the study:}

Water is one of the most important challenges confronting the 21st century because it has a great influence on the lives of many people. It has a strong connection with national security. Water is one of the most important factors that is directing to the spread of security.

The River Nile is the main source of development of Egypt. Nile water resources account for $97 \%$ of Egypt's accessible water resources. The 1959 agreement between Egypt and the Nile Basin estimated the average of the natural revenue of the river at Aswan at 84 billion cubic meters per year, distributed as 55.5 billion meters. Egypt is at the end of the Nile River at the source of the river makes Egypt in a challenging situation and more vulnerable to many problems and challenges of some countries of the basin to increase the exploitation of the Nile water, which reduces the fixed share obtained by Egypt and all this in light of the steady increase of Alaska. The increase in the consumption of some agricultural crops consumes acres of sugar cane about 10,000 cubic meters per year, equivalent to double the Beet consumption (which consumes 5,000 cubic meters per year) With the constant growth of population and climate change, there will be an expected water gap in Egypt. In 2025, the population will reach about 116 million. With Egypt's water resources stable, this will result in a water gap of about 49 billion cubic meters per year. Of water will be reduced to 620 cubic meters per

\footnotetext{
${ }^{1}$ Dewidar, H.H. and M.A. Marey, WATER RESOURCES AND FUTURE DEVELOPMENT IN EGYPT, Agricultural Economic Research Institute, Agricultural Research Center, J. Agric. Sci. Mansoura Univ., 8 (12): 10897 - 10911, 2009

${ }^{2}$ Decomposition a Further Step", Economics of agriculture Review, Vol. 28, Issue 6, 2017.
} 
year, which is below the water poverty line estimated at 1000 cubic meters per year, while studies confirm that by 2050 the water gap in Egypt will increase by an estimated population of 174 million, The water shortage will reach 94 billion cubic meters per year. $^{3}$

In terms of accounting, the previous challenges mentioned and the acute shortage of water requires the development of new mechanisms and methods of accounting to solve the problems facing the study of the costs of the possibility of developing and improving the efficiency of water transfer and distribution by applying modern control and irrigation systems, while reducing waste and improve the efficiency of utilization of the water unit, Rationalizing the use of available water and increasing agricultural productivity in an attempt to support the modern accounting methods resulting from the economic study presented in order to achieve the requirements of the overall quality and for the purposes of integration between the economic and accounting studies. ${ }^{4}$

\section{3-The hypothesis of the study:}

a- The rationalization of the consumption of water resources is an important alternative to accomplish water security.

b- - The application of modern irrigation systems can contribute significantly to reduce the deterioration of water consumption.

\section{4-The importance of the study:}

The importance of the current study originates from its attempt to explain the most important problems and challenges facing Egypt in the light of the crisis of AlNahda Dam and to present some of the proposed mechanisms to deal with the problems of water shortage in Egypt.

The support of modern accounting methods for economic studies at all stages planning, implementation achieves the continuous improvement desired as one of the requirements of the quality either in the study or in the tangible application of these studies on the one hand, and on the other hand is the critiques that lead to accounting after the tangible application Especially in light of the requirements of the total quality and the scarcity of research in this regard(case).

\section{5-The methodology of the study:}

${ }^{3}$ http://www.startimes.com

${ }^{4}$ Lennart Båge\&Luís Carlos Guedes Pinto, Our Planet, UNEP,WorldBank,2006,p.6 
The methodology of the study is the analytical method through the collection of data and information related to research, in addition to the use of logical conclusion by analyzing the problem of the research, its dimensions and characteristics besides the use of Arabic and foreign references, internet sites and available data on the subject with the economic calculation of the cost of developing and improving the efficiency of transportation and the distribution of water by implementing modern control systems to reduce losses and improve the efficiency of utilization of the water unit, and rationalize the use of available water and increase agricultural productivity.

\section{6-Literature Review}

Lundqvist (2000) tracks that the evolution of IWRM as a water resource management framework. His argument assumes that there is a great synergy between the Dublin Principles, and the water sector proposed (Lundqvist, 2000). The Dublin Principles from the international conference on water and environment held in Dublin, Ireland clearly articulate the relevance of IWRM with sustainable development. The study deduces that water is a recurring theme in sustainable development and it is organized as one of the essential tools for development. ${ }^{5}$

Allan (2003) argues that water resources management passed through five paradigms over the last 200 years. Integrated Water Resources Management (IWMR) is moving forward in creating better water use and management solutions. ${ }^{6}$

Water management is classified as integrated water resources management. The activity has many characteristics. On one hand, it focuses on sustainable development. On the other hand, it illustrates the concept of 'water scarcity' and its impacts on development (Jonker,2004) ${ }^{7}$.

\section{7- The most important means of rationalizing the use of irrigation water in}

\section{Egyptian agriculture:}

\footnotetext{
${ }^{5}$ Lundqvist, J (2000): Global Perspective on Water and the Environment: Physicsand Chemistry of the Earth. Vol. 25, No 3. pp 258-264.

${ }^{6}$ Allan, T., IWRM/IWRAM: a new sanctioned discourse? Occasional Paper50, SOAS Water Issues Study Group, School of Oriental and Studies/Kings College University of London.2003.

${ }^{7}$ Jonker,l.e.,integrated management segregated thinking, the case of water paper presented at the $5^{\text {th }}$ water net/warfsa symposium in Windhoek, Namibia, Nov. 2004.
} 
In the light of the steady increase of the number of people, the limited available agricultural natural resources in the country, the crisis of Al-Nahda Dam and the fears that may lead to a reduction of the amount of water delivered to Egypt. It is necessary to resort to many means to rationalize the use of irrigation water as it will be addressed to the modern methods to benefit from water and work on the good use, there are those who spend excessive use of water, making over-irrigation unnecessary and harmful, and others are trying to resort to ways that help to maintain water and ensure access equally hard and appropriate for the growth of their crops, but the misuse of the appropriate system for irrigation leads to the misuse of irrigation water and low efficiency, therefore we must use the appropriate systems that are in line with agricultural land conditions and working to treat water scarcity crisis and maintain.

\section{7-1 Reducing Water Intensive Crops:}

Sugar cane and rice crops are considered as the most important water intensive crops. Sugar cane is cultivated in Upper Egypt with a total area of less than half a million feddan. Most of its production is used in the operation of national sugar factories. Sugar cane consumption is about 10,000 cubic meters per year, twice the consumption of sugar beet, And the problem can be addressed through the development of irrigation systems for cane crop so as to reduce losses in water use and to consider the cultivation of other alternatives, such as the cultivation of stevia. As for the rice crop, the state's water plan to expand its area until 2017 focuses on reducing the area of rice from 1.3 million acres to 900 thousand feddans, but it has changed to the cultivation of new breeds of early maturity and less water consumption and higher productivity per feddan.

\section{$\underline{7-2}$ Reduce water network losses and generate additional resources ${ }^{8}$ :}

There are several projects in the Upper Nile with the aim of preserving water and reducing water losses, and raising additional resources, the most important projects are the following:

A. Desalination of sea water: to obtain hydraulic resources as well as to work on increasing water resources, especially as the cost decreases with the use of modern technologies. The water resources of seawater desalination is about 0.06 billion cubic meters and is expected to reach 0.14 billion cubic meters in 2017 .

\footnotetext{
${ }^{8}$ www.aoad.org/ftp/IrrigInternet.doc
} 
B. The Jonglei Canal project in southern Sudan: The project is supposed to provide about 4 billion cubic meters in the first phase and 3 billion cubic meters in the second phase divided equally between Egypt and Sudan.

C. Marshlands project in South Sudan: The project provides about 4 billion cubic meters of water.

D. Modification of the existing cropping structure: The need to modify the existing crop structure in line with the state's water, productivity and export policy and reduce the quantities of irrigation water for the cropland by planting beets instead of sugar cane and reducing the area of cultivated rice from 1.3 million feddans to 900 million feddans.

E. Reduction of water losses: The Ministry of Water Resources and Irrigation estimated the water losses at about $35 \%$ of the total water discharged from the High Dam, about 19.4 billion cubic meters, which is likely to be lost by leakage and evaporation. The loss of irrigation channels is 2.3 billion cubic meters annually.The strategy of irrigation development in Egypt aims at raising the efficiency of irrigation systems and conserving water resources by eliminating weeds and aquatic plants, which have a loss of about 0.75 billion cubic meters annually.

F. Bahr al-Ghazal project: which provides about 7 billion cubic meters of water equally between Egypt and Sudan.

\section{7-3 Expansion of land reclamation and cultivation:}

The need to work on the reclamation of old land and so that it should be distributed to young graduates and the role of the government to contribute to the infrastructure and the necessary studies to identify the best sites and provide the private sector with the credit required to finance those projects. ${ }^{9}$

\section{7-4 Sewage treatment:}

The Government intends to eliminate the problems of pollution of agricultural areas, which are the main obstacle to the expansion of reuse and the treatment of wastewater for reuse.

\footnotetext{
${ }^{9}$ Gosen J.; Babbar S. and Prasad S., "Quality and developing countries: the role of international and organizational factors", International Journal Brazilian Journal of Operations \& Production Management Volume 7, Number 1, 2010.
} 


\section{7-5 Irrigation scheduling:}

Which is determining the appropriate time for irrigation as well as determining the amount of irrigation needed, as this method is characterized by improving the production quantity, quality and rationalization of water, which reduces the cost of production ${ }^{10}$.

\section{7-6 Development of surface irrigation system and use of modern irrigation methods:}

Surface irrigation or flooding irrigation is defined as flooding of agricultural land with water from the canals. This type is common in areas where water is abundant near rivers, where water reaches the plants in this way through channels which are cracked in the ground or built, covered or exposed. Surface irrigation is considered as the least expensive, therefore one of the most common methods. ${ }^{11}$

It is necessary to develop and improve surface irrigation methods and raise its efficiency because it will provide large quantities of water, especially in the Arab world. For example, if the efficiency of surface irrigation in general increased by $5 \%$, this means that it is saving about 7 billion meters annually, so by this water more lands that were not irrigated will be irrigated, thus this will increase the agricultural production ${ }^{12}$.

In addition to work on modern irrigation methods in the new lands and in all lands in the valley and delta and the development of the common surface irrigation systems in the valley and the delta. In the past three decades, the government has been keen on implementing modern irrigation methods in the agricultural areas. However, most farmers do not follow these modern methods and convert modern irrigation methods to surface irrigation for relatively high maintenance costs. Modern irrigation methods are not suitable for some crops such as rice and sugar, which require large quantities of water, which waste water and money spent on modern irrigation systems. Based on the technical and economic feasibility studies,

10 Vikas Kumar, “ JIT Based Quality Management: Concepts and Implications in Indian Context”, International Journal of Engineering Science and Technology, Vol.2(1), 2010.

${ }^{11}$ Sharma Neha, Matharou Gurpreet Singh, Kaur Simran and Gupta Pramod, Lean Manufacturing Tools and Techniques in Process Industry; International Journal of Scientific,March,2013.

${ }^{12}$ http://www.sis.gov.eg. 
and in light of the general policy of the State and the Ministry of Public Works and Water Resources, whose conclusions and recommendations were necessary and inevitable

Development of irrigation systems The Development Sector initiated the preparation of the National Plan for the Future of Irrigation Development in the Old Lands until 2017 through the preparation of four five-year plans (Table 1) ${ }^{13}$

\section{Table (1)}

\section{Statement of the proposed five-year plans for irrigation development in the territories}

\section{Ancient Egypt until 2017}

\begin{tabular}{|l|l|l|l|}
\hline Plan & (thousand acres) & $\begin{array}{l}\text { Average cost per } \\
\text { acre (In pounds) }\end{array}$ & $\begin{array}{c}\text { Total cost } \\
\text { LE million }\end{array}$ \\
\hline $\begin{array}{l}\text { Plan during } \\
1996 / 1997\end{array}$ & 90 & 1800 & 162 \\
\hline $\begin{array}{l}\text { The Five - Year } \\
\text { Plan } \\
1997 / 2002\end{array}$ & 1046 & 2500 & 2631 \\
\hline $\begin{array}{l}\text { The Five Year } \\
\text { Plan } \\
2002 / 2007\end{array}$ & 1388 & 3100 & 4300 \\
\hline $\begin{array}{l}\text { The Five - Year } \\
\text { Plan } \\
2007 / 2012\end{array}$ & 2136 & 4000 & 8537 \\
\hline $\begin{array}{l}\text { The Five - Year } \\
\text { Plan } \\
2012 / 2017\end{array}$ & 2074 & 5000 & 10370 \\
\hline \begin{tabular}{l} 
Total \\
\hline
\end{tabular} & 6734 & & 26000 \\
\hline
\end{tabular}

\footnotetext{
${ }^{13}$ Source: Arab Organization for Agricultural Development, Study of the Development of Surface Irrigation and Drainage in Arab Countries, www.montadamohandiszira3.yoo7.com/t68-topic
} 
Source: Arab Organization for Agricultural Development, Study of the Development of Surface Irrigation and Drainage in Arab Countries, www.montadamohandiszira3.yoo7.com/t68-topic

In order to address the problem, the researcher will present the economic analysis of the surface irrigation systems according to the slopes of the slope and how they can be used and applied to the Egyptian economy to reduce water consumption and evaluate the financial feasibility on the long-term, so it will be easier to make the suitable decision which method to use to reduce the cost and consumption.

There are five irrigation systems that are marked in Appendix A, which include pipes, trenches and water-flow gates, as well as investment costs of each system. This is shown in Appendix A at the end of the study. There is a reduction in costs from system to another. When comparing the number of acres to be cultivated, the number of acres that are irrigated decreases when one of the five systems is chosen regardless of the difference and cost reduction of the system. Here the irrigation costs are studied 20, 30, 40 acres for the five systems. Experts have made considerable efforts to demonstrate surface irrigation systems that rationalize water consumption with lower cost. When comparing the cost of each system, the experts' efforts to reach a lower cost irrigation system with less water.

7.6.1 - Presentation of surface irrigation systems according to a study prepared by the University of Adhau, Moscow ${ }^{14}$

Experts of the University of Adhau in Moscow, have shown that there are five surface irrigation systems that show that water wastes can be rationalized by developing a surface irrigation system and moving from one system to another, this will lead to cost saving and rationalization of water consumption Which will have constructive results in the future, but the water can be retrieved again by $80 \%$ if the use of the Cablegation system, that the experts consider it as the best water consumption systems in terms of investment cost. All this is shown in the tables of the capital costs for each system.

The following systems are representing the surface irrigation systems, such as Siphon Tubes, Gated pipe system, Surge flow gated pipe system, Cablegation gated pipe system, as well as the Tailwater reuse systems.

\footnotetext{
${ }^{14}$ Robert L. Smathers, Bradley A. King, and Paul E. Patterson, Economics of Surface Irrigation Systems, University of Idaho cooperative Extension System, college of Agriculture, Bulletin No. 779. http://www.cals.uidaho.edu/edcomm/pdf/EXT/EXT0779.pdf
} 
A. Siphon system: it is a rigid or flexible pipe made of different materials (aluminum / plastic) and the water is transferred to the trenches, so it is necessary to make the level of the channel is higher than the level of the groove, and the amount of water transmitted by each siphon and the difference in the level between the height of the channel and the groove (load). The siphon diameter usually ranges between $20-60 \mathrm{~mm}$, but can be increased or decreased according to the use. The advantage of Siphon tubes is the ease of water flows and reaches almost all the cracks.

B. Gated pipe system: is known as the long-line irrigation system, which is a cheap American system. It costs almost $20 \%$ of the cost of sprinkler irrigation. This system achieves the efficiency of field irrigation to $80 \%$, which provides onethird of the amount of water used in irrigation.

C. The Surge Flow Gated Pipe System: is the supply of irrigation water in series of consecutive cycles of opening and closing of the water valve from the field to be irrigated so that it is irrigated at intervals of time, and with each cycle the water will advance and recede on A specific sector of the length of the field, which means the provision of water to the soil sporadically, leading to a change in soil leaks and thus a decrease in the permeability of the surface layer of the soil, which increases the efficiency of irrigation and savings in energy, labor and water with an increase in agricultural productivity of crops.

D. The Cablegation gated pipe system is based on features that make it a waterreducing device. The idea is to use a tube placed on the top of the sloping ground with openings so that each hole on the pipe provides a water line. The irrigation pipe contains a mobile plug connected to a rope that controls the passage of water in the pipe and the other end of the rope connected to a reel. During irrigation, the water is pushed along the pipe so that the number of lines that receive water increases over time. This, in turn, reduces the rate of water flowing in each discharge rate in proportion to the rate of drop in the infiltration rate, which in turn increases the efficiency of the irrigation system and reduces the amount of water loss.

\section{7-6-2- economic analysis for surface irrigation systems}

Tables A1 to A8 represents the capital requirements of the five systems which are the capital investment costs of irrigation systems Second: Economic analysis of surface irrigation systems 
Tables A1 to A8 illustrate the capital requirements of the five systems of as the capital investment costs of irrigation systems are inversely proportional to the length of the field and with the increased investment in irrigation of acres.

The total investment cost of the Siphon Tubes is $\$ 8,000.00$, and the average investment cost of irrigation per acre ranges from $\$ 388.00 /$ acre at 20 acres, $\$$ 149.00 / feddan at 40 acres. The total investment requirements for the Gated Pipe System is $\$ 4,052.00$, and the average investment cost per irrigation per acre ranges from $\$ 203.00$ thousand / feddan at 20 acres to 101.30 thousand dollars / fed at 40 acres. The total investment requirement for the Surge Flow Gated Pipe System is \$ $12,000.00$ and the average investment cost of irrigation per acre ranges from $\$$ 576.00 / feddan at 20 acres to $\$ 288.00$ thousand / fed at 40 acres. The total investment requirements for the Cablegation Gated Pipe System are \$6,470.00, and the average investment cost per irrigation per acre ranges from $\$ 324.00$ / feddan at 20 feddans to $\$ 162.00$ thousand / fed at irrigation 40 acres.

From the analysis above, we estimate that the minimum requirements for investment are obvious in the Cablegation Gated Pipe System and the highest cost of investment requirements is evident in the Siphon Tubes. However, the Siphon Pipeline system is less efficient and wastes a lot of water.Cablegation is the most efficient and consumes the least amount of water per minute for surface irrigation systems.

The following is an illustration of the annual costs as there are five annual cost systems that can be explained in Table A7 in the Annual Costs Annex. The data in the tables reveal the operating costs, the costs of ownership, maintenance, employment, depreciation, water quantity, interest on capital and investment for each system. ${ }^{15}$

The cost of ownership is based on alternating crops. One year of wheat and one year of barley and the third year of sugar beet. These crops require an average of the annual water supply of 21 inches and the average number of irrigation times per year is about 7 times alternating between the three crops. This was used to determine the labour costs of the five systems and the total cost of the gates and furniture $\$ 83.00$ per acre to irrigate 20 acres, $\$ 57.00$ per feddan when irrigated 40 acres, and the total

\footnotetext{
${ }^{15}$ Property costs are calculated by annual use instead of average method . the method of calculation is illustrated in appendix (B) at the end of the study . this method is more accurate and it allows any user to estimate the cost of (ownership ) or possession of equipment according to the different production age of every equipment
} 
annual costs of the Surge Flow Gated Pipe System is $121.25 \$$ / Acre to irrigate 20 acres, $\$ 76.00$ per acre when irrigated 40 acres. The Siphon system has an annual cost of $\$ 104.00$ / fed for irrigation of 20 acres, \$67.29 / fed for irrigation of 40 acres, as shown in Table A7.

We also assume that the annual cost data for the five systems in Table 7 that when compared to the other four systems, the Caplegation system has the lowest annual cost to the Siphon system, which is the highest in cost. The annual cost of the Siphon Irrigation system is 20,40 feddans $(\$ 105.00, \$ 69.37)$, respectively. The annual costing system is $\$ 90.00$ per acre for 20 acres, $\$ 59.77$ / acre for 40 acres. When compared to labour costs, we also find that the Caplegation system is one of the least expensive systems for labour, because the labour required for this system is one-third of the labour needed by the Siphon system, and the other systems require half of the required labour for the Siphon system. If the lowest cost is the Caplegation system and the highest cost is the Siphon system, so the researcher sees that the use of the Caplegation system is one of the best systems to develop the surface irrigation system.

Annual cost recovery can be recovered from crop output. If we cultivate three crops on a rotating basis, it is expected that costs will be recovered and profits will be realized. For example, if we are conducting a study on wheat irrigation with the Caplegation system for surface irrigation, we find that if the wheat is grown only in its season, the annual cost of the wheat crop can only be recovered and a return is obtained from it (back to the table of wheat investment in the appendix at the end of the study).

7-6-3- How the Egyptian economy can benefit from previous experiences to address water shortage

In the light of the pilot experiences of countries that have suffered from the water scarcity crisis and have been able, through their management and taking the necessary strategic measures to provide their citizens' water needs using many new means and technologies. The Egyptian economy can benefit from these experiences as follows: ${ }^{16}$

A. Determining the price of water according to the irrigated area and lining irrigation channels.

Hans Hartung, The benefits and risksof solar-powered irrigation- a global overview,fao,2018 16 
B. Reuse of wastewater and construction of water treatment plants to recycle and use wastewater for industrial purposes and study the relationship between soil and water as well as enacting laws governing the process of rationalization of water and prevention of pollution and method of use.

C. Raising the efficiency of irrigation and the introduction of modern irrigation methods such as drip irrigation and spray, also the development of new strains and varieties of crops consume less water.

D. Benefit from the Israeli experience by working on desalination of solar water using solar panels to run the pumps of desalination units that generate pure water, which works to reduce water consumption and reduce the costs of energy and electricity use, and in the case of application In Egypt, the price per cubic meter of desalinated water will reach 3 pounds instead of 10 pounds ${ }^{17}$.

E. Use of modern techniques for growing rice called "Shallow water depth" instead of the traditional immersion method.

F. Legislate laws and giving the material incentive to encourage rational use of water.

\section{8 -Results and Recommendations:}

\section{8-1-Results}

The research, in which we proved in the end that the first and second assumptions, which provide the following : A-The rationalization of the consumption of water resources is considered an important alternative to achieve water security. B-The implementation of modern irrigation systems can contribute significantly to reduce water wastes.

A. The capital requirements for the five systems in the tables from A1 to A8 at the end of the study illustrates that the capital investment costs of the irrigation systems are inversely proportional to the length of the field and with the increased investment in irrigation of the acres.

\footnotetext{
${ }^{17}$ Precision Agriculture Looking Forward to 2030, For World Food Day, 16 October 2018, http://www.israelagri.com/
} 
B. The total investment costs of the Siphon Tubes is $\$ 8,000.00$, and the average investment cost per irrigation per acre ranges from $\$ 388.00 /$ acre at 20 acres, $\$ 149.00$ / fed at 40 acres. The total investment requirements for the Gated Pipe System are $\$ 4,052.00$, and the average investment cost per irrigation per acre ranges from $\$ 203.00$ thousand / feddan at 20 riyals

C. Acres to 101.30 thousand dollars/acres when irrigation 40 acres. The total investment requirement for the Surge Flow Gated Pipe System is \$12,000.00 and the average investment cost per irrigation per acre ranges from $\$ 576.00 /$ feddan at 20 acres to $\$ 288.00$ thousand / fed at 40 acres. The total investment requirements for the Cablegation Gated Pipe System are \$ $6,470.00$, and the average investment cost per irrigation per acre ranges from $\$ 323.50$ / feddan at 20 feddans to $\$ 162.00$ thousand / fed at irrigation 40 acres

D. -The minimum requirements for investment are obvious in the Cablegation Gated Pipe System, and the highest cost of investment is evident in the Siphon Tubes. However, the Siphon Pipeline system is less efficient and wasteful in water. The most efficient use less amount of water per minute for surface irrigation systems.

E. Ownership costs were based on alternating crops. One year of wheat and one year of barley and the third year of sugar beet. These crops require an average annual water supply of 21 inches and the average number of irrigation times per year is about 7 times alternating between the three crops. This was used to determine the labour costs of the five systems, the total cost of gates and furniture, $\$ 83.00$ per acre for irrigation of 20 acres, $\$ 57.00$ per feddan at 40 acres, and the total annual cost of the Surge Flow Gated Pipe System is \$ 121.25 / fed for 20 acres, Dollars per feddan when irrigation 40 acres. The Siphon system has an annual cost of \$104.00 / acre to irrigate 20 acres, \$ 67.29 / acre to irrigate 40 acres.

F. -Data on the annual costs of the five systems under study indicate that, when compared to the other four systems, the Capligation system has the lowest annual cost to the SIVON system, which is the highest cost, and other systems. The annual cost of the Siphon Irrigation system is 20,40 feddans (\$ $105.00, \$ 69.37)$, respectively. The annual costing system is $\$ 90.00$ per acre for 20 acres, $\$ 59.77$ / acre for 40 acres. When compared to labour costs, we also find that the caplegation system is one of the least expensive systems for labour, because the labour required for this system is one-third of the labour 
needed by the Siphon system, and the other systems require half of the required labour for the Siphon system. If the lowest cost is the caplegation system and the highest cost is the Siphon system, so the researcher sees that the use of the Caplegation system is one of the best systems to develop the surface irrigation system. Annual cost recovery can be recovered from crop output. If we cultivate three crops on a rotating basis, it is expected that costs will be recovered and profits will be realized.

\section{8-2-Recommendations}

Based on the results reached in the economic study, the researchers recommend the following:

A. It is necessary to develop and improve the method of surface irrigation and raise its efficiency because it will provide large amounts of water, especially in the Arab world. For instance, if the efficiency of surface irrigation in general increased by $5 \%$, this means it saves about 7 billion Cubic meters per year so it can irrigate areas of land that were not irrigated originally, thus it can increase the agricultural production.

B. The need to use modern irrigation methods in the new lands and in different lands in the valley and delta and the development of surface irrigation systems prevailing in the valley and delta. In the past three decades, the government has been keen on using modern irrigation methods. However, most farmers do not follow these modern methods and into the new irrigation methods of surface irrigation for relatively high maintenance costs. Modern irrigation methods which are not suitable for some crops such as rice and sugar, which require large supplies of water. This leads to waste. Water and money spent on modern irrigation systems.

C. Determining the price of water according to the irrigated area and lining irrigation channels.

D. Reuse of water wastes and manufacture of water treatment plants to recycle and use wastewater for industrial purposes and study the relationship between soil and water as well as enacting laws governing the process of rationalization of water and prevention of pollution and the manner of use.

E. Raising the efficiency of irrigation and the introduction of modern irrigation methods such as drip irrigation and spraying, also the development of new strains and varieties of crops consume less water 
F. Use modern rice cultivation techniques called "shallow water depth" instead of conventional immersion method.

G. The legislation of laws and the provision of a material incentive to encourage the rationalization of water use.

H. The concerned bodies in the State encourage and stimulate the use and application of modern irrigation systems that contribute to saving water and waste, especially those supported by economic studies based on modern methods to solve problems with zero defects instead of entering failed experiments in a critical material such as water, In any form of encouragement and motivation.

I. Provide a database with data and information that help decision makers to get acquainted with the latest research in this field in order to differentiate between them and the trend to rely more on scientific research in solving the problems facing the Egyptian society.

\section{References}

\section{A-PERIODICALS}

1. Allan, T., 2003. IWRM/IWRAM: a new sanctioned discourse? Occasional Paper50, SOAS Water Issues Study Group, School of Oriental and Studies/Kings College University of London.

2. Decomposition a Further Step", Economics of agriculture Review, Vol. 28, Issue 6, 2017.

3. Dewidar, H.H. and M.A. Marey, WATER RESOURCES AND FUTURE DEVELOPMENT IN EGYPT, Agricultural Economic Research Institute, Agricultural Research Center, J. Agric. Sci. Mansoura Univ., 34 (12): 10897 - 10911, 2009.

4. Gosen J.; Babbar S. and Prasad S., "Quality and developing countries: the role of international and organizational factors", International Journal Brazilian Journal of Operations \& Production Management Volume 7, Number 1, 2010.

5. Hans Hartung, The benefits and risksof solar-powered irrigation- a global overview,fao,2018. 
6. Jonker,l.e.(2004),integrated management segregated thinking, the case of water paper presented at the $5^{\text {th }}$ water net/warfsa symposium in Windhoek, Namibia, Nov. 2004.

7. Lennart Båge \& Luís Carlos Guedes Pinto, Our Planet, UNEP, WorldBank,2006 ISSN 101-7394,.

8. Lundqvist, J (2000): Global Perspective on Water and the Environment: Physicsand Chemistry of the Earth. Vol. 25, No 3. pp 258-264.

9. Robert L. Smathers,Bradley A. King,and Paul E. Patterson,Economics of Surface Irrigation Systems, University of Idaho cooperative Extension System, college of Agriculture, Bulletin No. 779,

http://www.cals.uidaho.edu/edcomm/pdf/EXT/EXT0779.pdf

10. Sharma Neha, Matharou Gurpreet Singh, Kaur Simran and Gupta Pramod, Lean Manufacturing Tools and Techniques in Process Industry ; International Journal of Scientific,March,2013.

11. Smith, Gerald W. Engineering Economy: Analysis of Capital Expenditures, Iowa State University Press, 1973, pp. 93-98.

12. Vikas Kumar, " JIT Based Quality Management: Concepts and Implications in Indian Context", International Journal of Engineering Science and Technology, Vol.2(1), 2010.

\section{B: Internet}

1. Arab Organization for Agricultural Development, Study of the Development of Surface Irrigation and Drainage in Arab Countries, www.montadamohandiszira3.yoo7.com/t68-topic

2. Precision Agriculture Looking Forward to 2030, For World Food Day, 16 October 2018, http://www.israelagri.com/

3. http://www.sis.gov.eg.

4. www.aoad.org/ftp/IrrigInternet.doc 


\section{Appendix A}

\section{Cost Summaries}

\section{Table A1. Capital Investment for Earthen Head Ditch with Siphon Tubes. ${ }^{1}$}

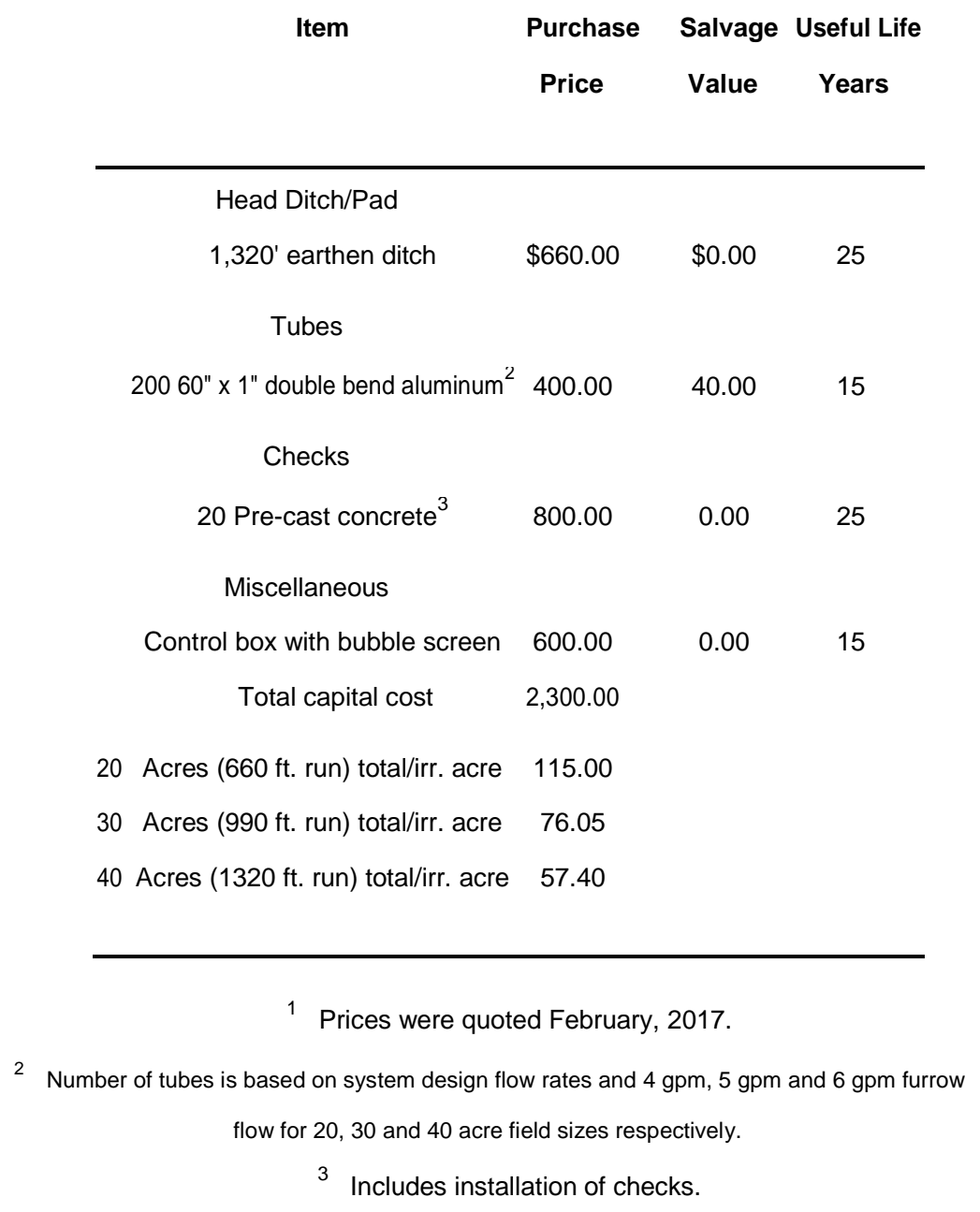


Table A2. Capital Investment for Concrete Head Ditch with Siphon Tubes. ${ }^{1}$

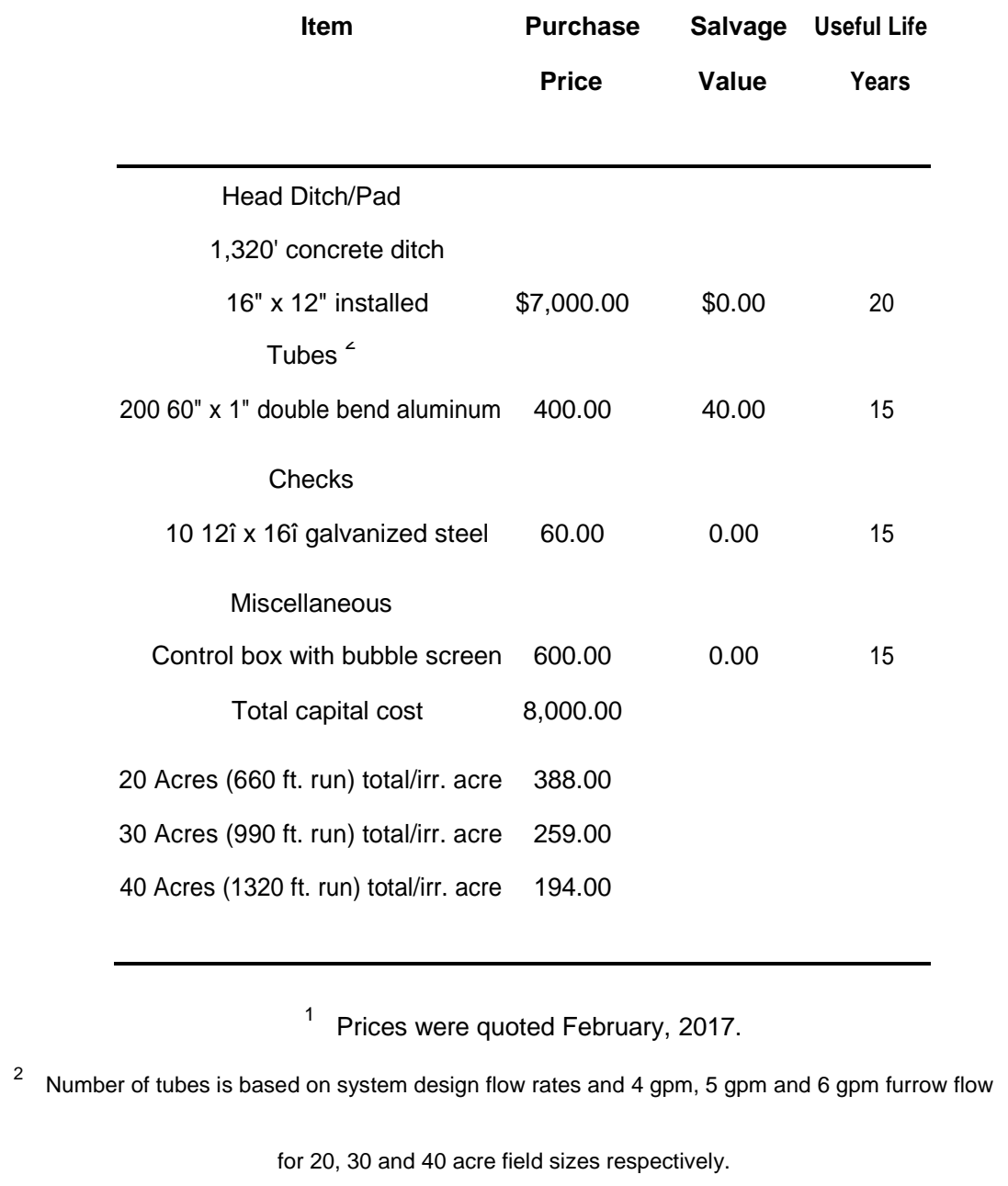


Table A3. Capital Investment for a 1/4 mile Gated Pipe System. ${ }^{1}$




Table A4. Capital Investment for a 1/4 mile Surge Flow Gated Pipe System. ${ }^{1}$

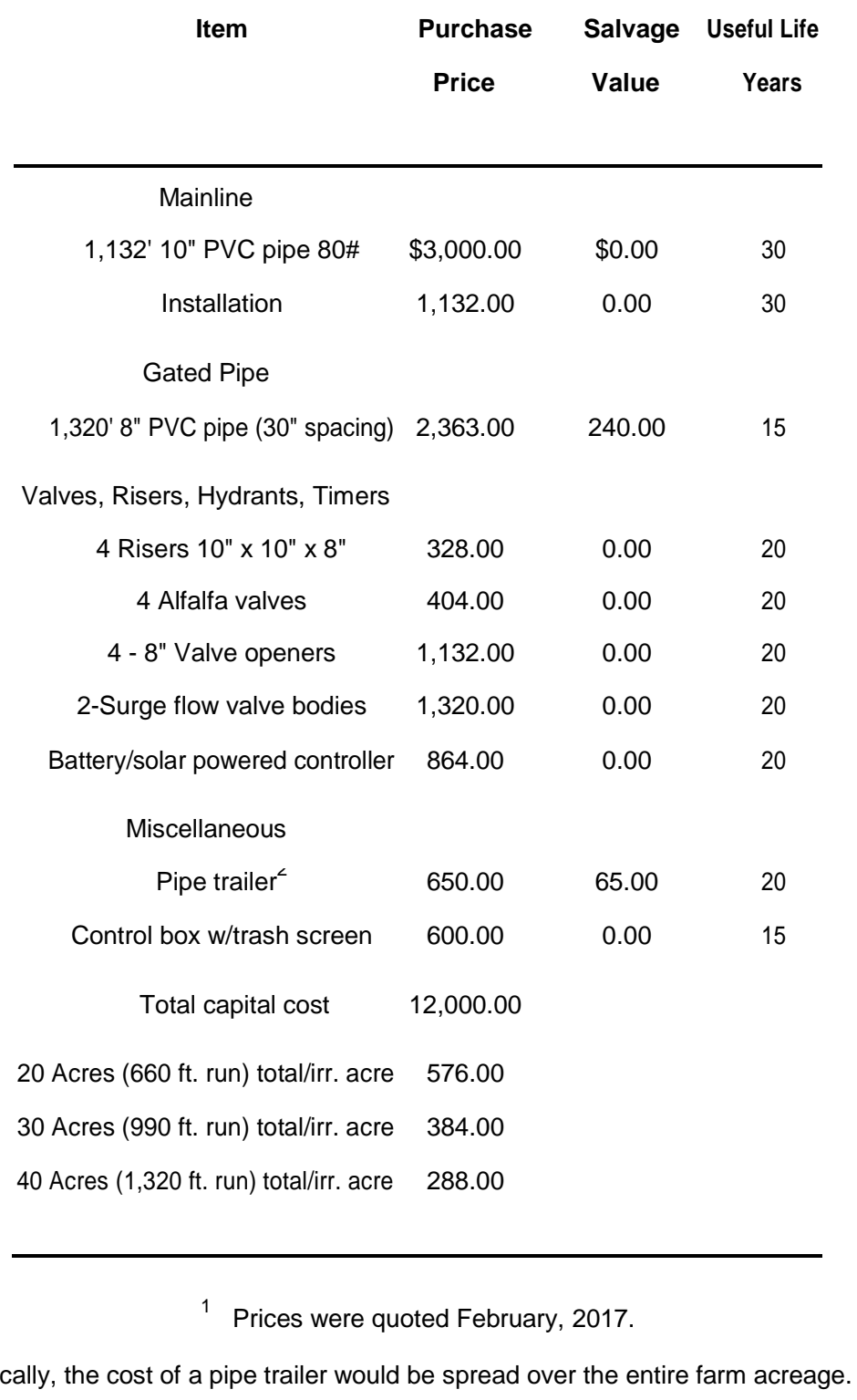


Table A5. Capital Investment for a 1/4 mile Cablegation Gated Pipe System. ${ }^{1}$

\begin{tabular}{|c|c|c|c|}
\hline Item & $\begin{array}{c}\text { Purchase } \\
\text { Price }\end{array}$ & $\begin{array}{l}\text { Salvage } \\
\text { Value }\end{array}$ & $\begin{array}{c}\text { Useful Life } \\
\text { Years }\end{array}$ \\
\hline \multicolumn{4}{|l|}{ Gated Pipe w/Spigot Gates } \\
\hline 1,320 10" PVC (30" spacing) & $\$ 3,736.00$ & $\$ 374.00$ & 20 \\
\hline Graded pad and installation & $1,320.00$ & 0.00 & 20 \\
\hline \multicolumn{4}{|l|}{ Miscellaneous } \\
\hline 1,350'-3/16" Polypropyline cable & 54.00 & 0.00 & 5 \\
\hline 1-10" Cablegation plug & 60.00 & 0.00 & 5 \\
\hline \multicolumn{2}{|c|}{ Cable release mechanism - electronic 700.00} & 0.00 & 10 \\
\hline Control box w/bubble screen & 600.00 & 0.00 & 15 \\
\hline Total capital cost & $6,470.00$ & & \\
\hline 20 Acres (660 ft. run) total/irr. acre & 324.00 & & \\
\hline 30 Acres (990 ft. run) total/irr. acre & 216.00 & & \\
\hline 40 Acres (1320 ft. run) total/irr. acre & 162.00 & & \\
\hline
\end{tabular}


TableA6. Capital Investment for Pump Back System for Surface Irrigation

(20 Acre Field). ${ }^{1}$

\begin{tabular}{|c|c|c|c|}
\hline Item & $\begin{array}{l}\text { Purchase } \\
\text { Price }\end{array}$ & $\begin{array}{c}\text { Salvage } \\
\text { Value }\end{array}$ & $\begin{array}{c}\text { Useful Life } \\
\text { Years }\end{array}$ \\
\hline \multicolumn{4}{|l|}{ Mainline } \\
\hline 1,475' 6" PVC pipe 80\# & $\$ 1,239.00$ & $\$ 0.00$ & 30 \\
\hline Installation charge & $1,475.00$ & 0.00 & 30 \\
\hline \multicolumn{4}{|l|}{ Pumping Equipment } \\
\hline \multicolumn{4}{|l|}{ Pump \& motor } \\
\hline$(1 \mathrm{HP}) /$ base $\&$ housing & $1,172.00$ & 117.00 & 20 \\
\hline Suction and discharge & 360.00 & 0.00 & 20 \\
\hline Electrical panel and wiring & $1,100.00$ & 110.00 & 20 \\
\hline Installation/setup charge & 270.00 & 0.00 & 20 \\
\hline Power installation (1/8 mile $)^{3}$ & 660.00 & 0.00 & 30 \\
\hline \multicolumn{4}{|l|}{ Reservoir } \\
\hline $274 \mathrm{yd}^{3}{ }^{3}$ pond w/overflow structure & 500.00 & 0.00 & 5 \\
\hline Total capital cost & $7,000.00$ & & \\
\hline Total per acre & 334.00 & & \\
\hline
\end{tabular}

1 This pump back system is designed for conventional surface irrigation using gated pipe or siphon tubes and ditch.

2 Includes screen, vacuum, air relief valves, control valve, foot valve, priming system, and piping.

3 Power installation cost depends on distance from power source and installer. This example assumes that electrical panel is only $1 / 8$ mile from power source and owner installs ditch, wire, and conduit. 
Table A7. Capital Costs for Pump Back System for Surface Irrigation (30 Acre Field). ${ }^{1}$

\begin{tabular}{|c|c|c|c|}
\hline Item & $\begin{array}{c}\text { Purchase } \\
\text { Price }\end{array}$ & $\begin{array}{l}\text { Salvage } \\
\text { Value }\end{array}$ & $\begin{array}{c}\text { Useful Life } \\
\text { Years }\end{array}$ \\
\hline \multicolumn{4}{|l|}{ Mainline } \\
\hline 1,650' 6" PVC pipe 80\# & $\$ 1,386.00$ & $\$ 0.00$ & 30 \\
\hline Installation charge & $1,650.00$ & 0.00 & 30 \\
\hline \multicolumn{4}{|l|}{ Pumping Equipment } \\
\hline \multicolumn{4}{|l|}{ Pump \& motor } \\
\hline$(1.5 \mathrm{HP}) /$ base $\&$ housing & $1,200.00$ & 120.00 & 20 \\
\hline Suction and discharge ${ }^{<}$ & 368.00 & 0.00 & 20 \\
\hline Electrical panel and wiring & $1,100.00$ & 110.00 & 20 \\
\hline Installation/setup charge & 276.00 & 0.00 & 20 \\
\hline Power installation (1.8 mile) ${ }^{3}$ & 660.00 & 0.00 & 30 \\
\hline \multicolumn{4}{|l|}{ Reservoir } \\
\hline \multicolumn{4}{|l|}{$411 \mathrm{yd}^{u}$ pond } \\
\hline w/overflow structure & 700.00 & 0.00 & 5 \\
\hline Total capital cost & $7,240.00$ & & \\
\hline Total per acre & 241.33 & & \\
\hline
\end{tabular}

1 This above pump back system is designed for conventional surface irrigation using gated pipe or siphon tubes and ditch.

2 Includes screen, vacuum, air relief valves, control valve, foot valve, priming system, and piping.

3 Power installation cost depends on distance from power source and installer.

This example assumes that electrical panel is only $1 / 8$ mile from

power source and owner installs ditch wire and conduit. 
Table A8. Capital Investment for Pump Back System for Surface Irrigation (40 Acre Field). ${ }^{1}$

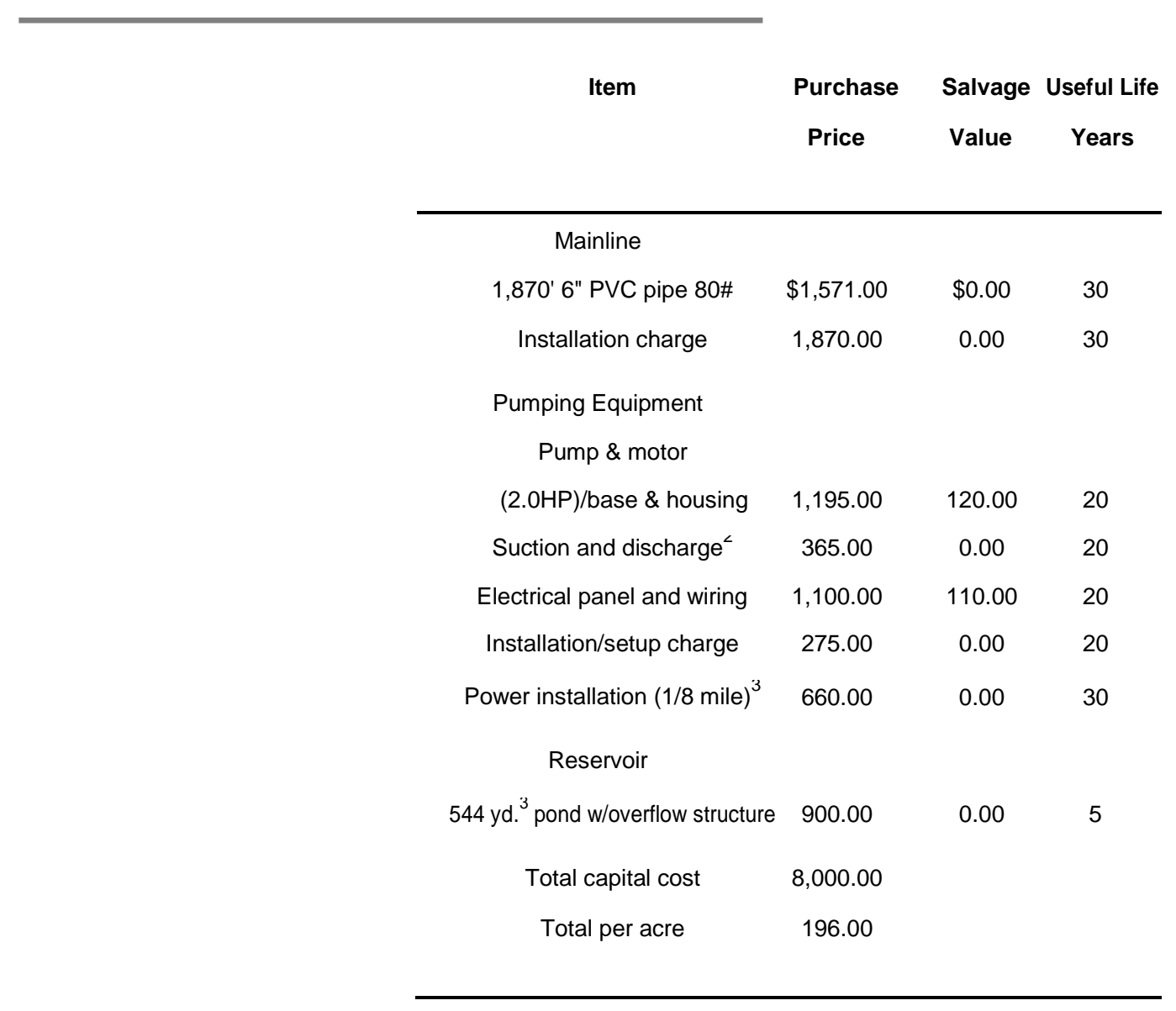

1 This pump back system is designed for conventional surface irrigation using gated pipe or siphon tubes and ditch.

2 Includes screen, vacuum, air relief valves, control valve, foot valve, priming system, and piping.

3 Power installation cost depends on distance from power source and installer. This example assumes that electrical panel is only $1 / 8$ mile from power source and owner installs ditch, wire, and conduit. 


\section{Appendix B}

\section{Ownership Cost Calculations}

Depreciation and interest is calculated using an exact technique that finds the annual equivalent of first cost less annual equivalent of salvage. This method was chosen over the estimated technique using straight-line depreciation (repayment) plus return on the average investment. When using the estimated technique the magnitude of error increases as: (1) years of useful life increase and (2) interest rate increases.

$$
\begin{aligned}
& =\mathrm{B}\left(\not^{\prime} \mathrm{n}-\mathrm{v}\left(\not^{\prime} \mathrm{n}\right.\right. \\
& \text { Depreciation and Interest a } \quad \text { i } \quad \text { a } \quad \text { i } \\
& \text { where } \mathrm{B} \quad=\text { initial investment } \\
& \mathrm{v} \quad=\quad \text { salvage value } \\
& \text { i }=\text { interest rate in decimal } \\
& \mathrm{n}=\text { years of useful life }
\end{aligned}
$$



sinking fund factor. 


\section{Insurance}

Source: Smith, Gërald W. Engineering Economy: Analysis of Capital Expenditures, lowa State University Press, 1973, pp. 93-98.

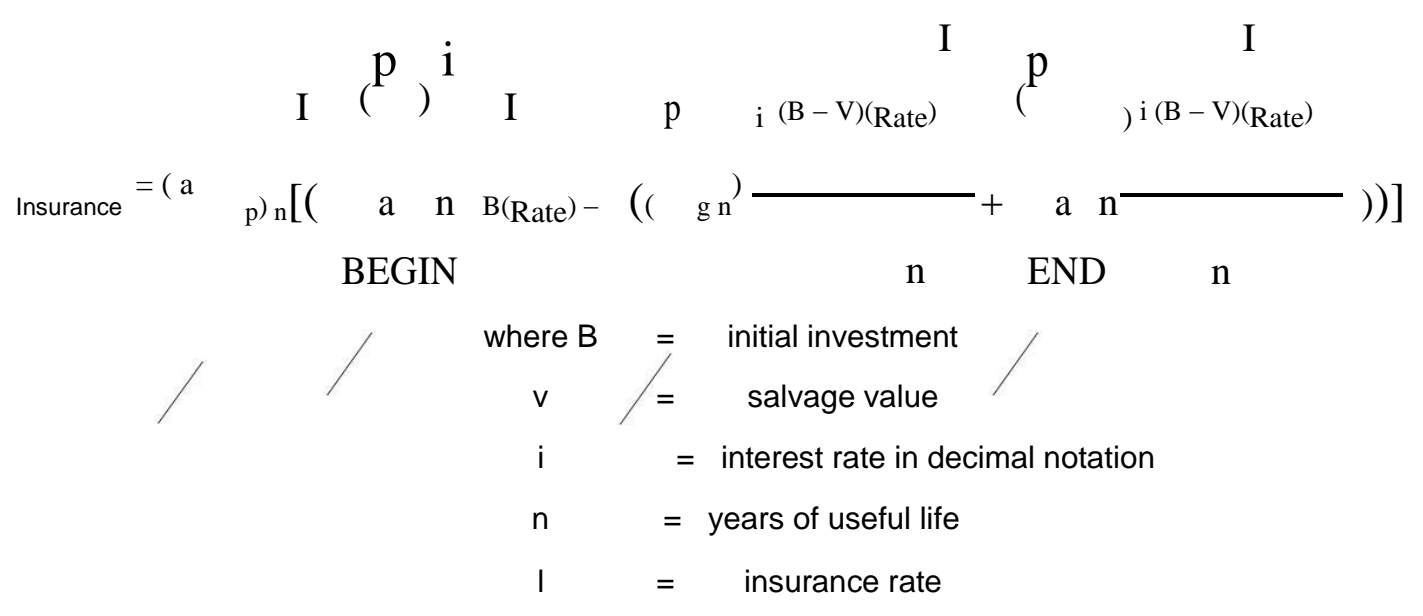

$$
\begin{aligned}
& \text { a } \mathrm{i} \\
& ()^{\prime}=\mathrm{i}(1+\mathrm{i})^{\mathrm{n}} \\
& / \mathrm{p} \text { n } \overline{(1+\mathrm{i})^{\mathrm{n}}-1}
\end{aligned}
$$


= uniform series end-of-period amount (a) equivalent to present sum, (p); or capital

$$
\begin{aligned}
& (\mathrm{r} \quad)^{{ }_{1}}\left((1+\mathrm{i})^{\mathrm{n}}-1\right)(1+i)=\text { present sum }(\mathrm{p}) \text { equivalent to } \\
& \text { a } \quad \mathrm{n}=\longrightarrow_{\mathrm{n}} \text { uniform beginning-of-period } \\
& \text { BEGIN } \quad \mathrm{i}(1+\mathrm{i}) \quad \text { series (a). } \\
& \left(\mathrm{p}^{1}\right)^{1}=1\left[(1+\mathrm{i})^{\mathrm{n}}-1-\mathrm{n}\right]^{=} \text {present sum }(\mathrm{p}) \text { equivalent } \\
& \int \mathrm{gn} \quad \overline{\mathrm{i}} \overline{\mathrm{i}(1+\mathrm{i})^{\mathrm{n}}}\left(\overline{(1+\mathrm{i})^{\mathrm{n}}} \quad \text { to gradient series }(\mathrm{g})\right. \text {. } \\
& (\mathrm{p} \quad)^{1}(1+\mathrm{i})^{\mathrm{n}}-1 \\
& \text { END } \quad \mathrm{i}(1+\mathrm{i})^{\mathrm{n}} \\
& \text { BEGIN = payments in advance END = payments in arrears. }
\end{aligned}
$$

Source: Formula developed by David J. Walker, Assistant Professor and Brian L. Calkins, Graduate Student, Agricultural Economics and Applied Statistics, University of Idaho. 